Louisiana State University

LSU Digital Commons

$1-1-2014$

\title{
A new species of Eimeria Schneider, 1875 (Apicomplexa: Eimeriidae) from the Solomon ground skink, Sphenomorphus solomonis (Boulenger) (Sauria: Scincidae) from Papua New Guinea
}

Chris T. McAllister

Eastern Oklahoma State College

Donald W. Duszynski

The University of New Mexico

Robert N. Fisher

United States Geological Survey

Christopher C. Austin

Louisiana State University

Follow this and additional works at: https://digitalcommons.Isu.edu/biosci_pubs

\section{Recommended Citation}

McAllister, C., Duszynski, D., Fisher, R., \& Austin, C. (2014). A new species of Eimeria Schneider, 1875 (Apicomplexa: Eimeriidae) from the Solomon ground skink, Sphenomorphus solomonis (Boulenger) (Sauria: Scincidae) from Papua New Guinea. Systematic Parasitology, 87 (1), 83-86. https://doi.org/ 10.1007/s11230-013-9455-2

This Article is brought to you for free and open access by the Department of Biological Sciences at LSU Digital Commons. It has been accepted for inclusion in Faculty Publications by an authorized administrator of LSU Digital Commons. For more information, please contact ir@lsu.edu. 


\title{
A new species of Eimeria Schneider, 1875 (Apicomplexa: Eimeriidae) from the Solomon ground skink, Sphenomorphus solomonis (Boulenger) (Sauria: Scincidae) from Papua New Guinea
}

\author{
Chris T. McAllister • Donald W. Duszynski • \\ Robert N. Fisher - Christopher C. Austin
}

Received: 5 September 2013 / Accepted: 24 October 2013

(C) Springer Science+Business Media Dordrecht 2013

\begin{abstract}
Between September 1990 and November 1991, 19 Sphenomorphus spp. skinks, including nine $S$. jobiense, three $S$. simus, and seven Solomon ground skinks, S. solomonis (Boulenger), were collected from Madang and Morobe Provinces, Papua New Guinea (PNG), and examined for coccidia. A single S. solomonis was found to be infected with a new species of Eimeria Schneider, 1875. Oöcysts of Eimeria perkinsae n. sp. are ellipsoidal with a smooth, colourless, bi-layered wall, measure $18.6 \times 14.7 \mu \mathrm{m}$, and have a length/width (L/ $\mathrm{W})$ ratio of 1.3 ; both micropyle and oöcyst residuum are absent, but a fragmented polar granule is present. Sporocysts are ovoidal, $8.9 \times 6.4 \mu \mathrm{m}$, L/W 1.4; neither Stieda, sub-Stieda or para-Stieda bodies are present; a sporocyst residuum consisted of a loose cluster of
\end{abstract}

\section{T. McAllister $(\bowtie)$}

Division of Science and Mathematics, Eastern Oklahoma State College, Idabel, OK 74745, USA

e-mail: cmcallister@se.edu

D. W. Duszynski

Department of Biology, University of New Mexico, Albuquerque, NM 87131, USA

R. N. Fisher

U.S. Geological Survey, Western Ecological Research Center, San Diego Field Station, 4165 Spruance Road, Suite 200, San Diego, CA 92101-0812, USA

\section{C. Austin}

Department of Biological Sciences, Museum of Natural Sciences, Louisiana State University, Baton Rouge, LA 70803, USA granules dispersed between sporozoites. Sporozoites are comma-shaped with spheroidal anterior and posterior refractile bodies. This represents the first report of coccidia from this skink genus.

\section{Introduction}

Scincidae is the largest family of lizards with approximately 1,500 described species, representing about $25 \%$ of all lizard diversity (Uetz, 2013). Skinks can be found on all the warm continents and exhibit the greatest variety of morphological, physiological, behavioural, reproductive, and life history variation seen in any reptile family. Skinks in the subfamily Lygosominae have their centre of species richness in Australasia (Skinner et al., 2011). The lygosomid skink genus Sphenomorphus Fitzinger (tribe Sphenomorphini) is a large and highly diverse group of lizards containing about 120 described species (Uetz, 2013) that has had a long and difficult taxonomic history and very little is known about their parasites. Kreis (1940), Bursey et al. (2005) and Goldberg et al. (2009, 2010) provided descriptions of new helminth species from Sphenomorphus jobiensis Meyer from Papua New Guinea (PNG). In addition, Austin \& Perkins (2006) and Perkins \& Austin (2009) reported hematozoa from S. jobiensis from PNG. However, nothing is known about coccidian parasites of any member of the genus. Here, we provide a description of a new species of Eimeria Schneider, 1875 from S. solomonis (Boulenger) from PNG. 


\section{Materials and methods}

Between September 1990 and November 1991, 19 Sphenomorphus spp. skinks were collected by hand or shot with a dart from a blowpipe from Madang $(\mathrm{n}=6)$ and Morobe $(\mathrm{n}=13)$ provinces, $\mathrm{PNG}$ as follows: nine S. jobiense, three $S$. simus, and seven $S$. solomonis. Fresh faeces were collected and placed in individual vials containing $2.5 \%(\mathrm{w} / \mathrm{v})$ aqueous potassium dichromate $\left(\mathrm{K}_{2} \mathrm{Cr}_{2} \mathrm{O}_{7}\right)$ and examined for coccidia by light microscopy after flotation in Sheather's sugar solution (specific gravity $=1.30$ ). Measurements were taken on 20 sporulated oöcysts using a calibrated ocular micrometer and reported in micrometres with means followed by the ranges in parentheses; photomicrographs were taken using Nomarski interference-contrast optics. Oöcysts were $c .300$ days old when measured and photographed. Descriptions of oöcysts and sporocysts follow guidelines of Wilber et al. (1998) as follows: oöcyst length (L) and width (W), their ranges and ratios (L/W), micropyle (M), oöcyst residuum (OR), polar granules (PG), sporocyst (SP) length (L) and width (W), their ranges and ratio (L/W), sporocysts (SP), Stieda body (SB), subStieda body (SSB), para-Stieda body (PSB), sporocyst residuum (SR), sporozoites (SZ) anterior (ARB) and posterior (PRB) refractile bodies, and nucleus (N). Skink voucher specimens were accessioned into the California Academy of Sciences (CAS), San Francisco, California, USA as 192848-51, 192881, 243309, and the Texas Natural History Collection (TNHC), Austin, Texas, USA as TNHC 51251, 51259, 51262-66, 51273-75, 51349, 52113-14. Photosyntypes of sporulated oöcysts were accessioned into the United States National Parasite Collection (USNPC), Beltsville, Maryland, USA. Lizard taxonomy follows the reptile database (Uetz, 2013) and Zug (2013).

\section{Results}

One of 19 (5\%) Sphenomorphus spp. skinks was found to be passing an undescribed species of Eimeria, which is described below.

\section{Eimeria perkinsae $\mathbf{n}$. sp.}

Type-host: Solomon ground skink, Sphenomorphus solomonis (Boulenger), symbiotype TNHC 51265 (field no. CCA 0463) collected 26 September 1991.
Type-locality: Papua New Guinea, Morobe Province, Bakia Village No. $1\left(7^{\circ} 57^{\prime} 50^{\prime \prime} \mathrm{S}, 147^{\circ} 11^{\prime} 16^{\prime \prime} \mathrm{E}\right)$, elevation $900 \mathrm{~m}$.

Type-material: Photosyntype deposited as USNPC 106980.

Prevalence: 1 of 7 (14\%).

Sporulation time: Unknown. Specimens were collected in the field, stored in $\mathrm{K}_{2} \mathrm{Cr}_{2} \mathrm{O}_{7}$ solution, and not examined until 300 days later.

Site of infection: Unknown. Oöcysts were passed in faeces and host tissues were not collected or preserved for histological sectioning.

Etymology: The specific epithet is a matronym in honour of Dr. Susan L. Perkins, American Museum of Natural History, New York, New York, USA, in recognition of her contributions to lizard hemoparasite biology, particularly on Sphenomorphus spp. skinks from PNG.

\section{Description (Figs. 1-3)}

\section{Sporulated oöcyst}

Ö̈cyst $(\mathrm{n}=20)$ colourless, smooth, ellipsoidal; $18.7 \times 14.7(16-20 \times 13-16)$; length/width $(\mathrm{L} / \mathrm{W})$ ratio 1.3 (1.2-1.5). Wall bi-layered, with equal thickness $c .0 .5$ (0.4-0.6). Micropyle absent, oöcyst residuum absent; fragmented polar granule present.

\section{Sporocyst}

Sporocysts $(\mathrm{n}=20)$ four, colourless, smooth, ovoidal, $8.9 \times 6.4(7-10 \times 6-7) ; \mathrm{L} / \mathrm{W}$ ratio $1.4(1.1-1.7)$; wall single-layered c.0.5. Stieda body, sub-Stieda body, and para-Stieda body absent; sporocyst residuum consists of loose cluster of granules dispersed between sporozoites.

\section{Sporozoite}

Sporozoites (not measured) two, comma-shaped; with single spheroidal anterior refractile body, 1.3 (1.0-1.6) $(\mathrm{n}=5)$, and spheroidal posterior refractile body, 2.4 $(2.3-2.4)(n=5)$, with nucleus between them.

\section{Remarks}

There are two similar eimerians reported previously from lizards of the family Scincidae that possess ovoidal oöcysts with mean lengths $<20 \mu \mathrm{m}$ and with L/W ratios of $c .1 .3$ as follows: Eimeria lampropholidis Cannon, 1967 from pale-flecked garden sunskink, 

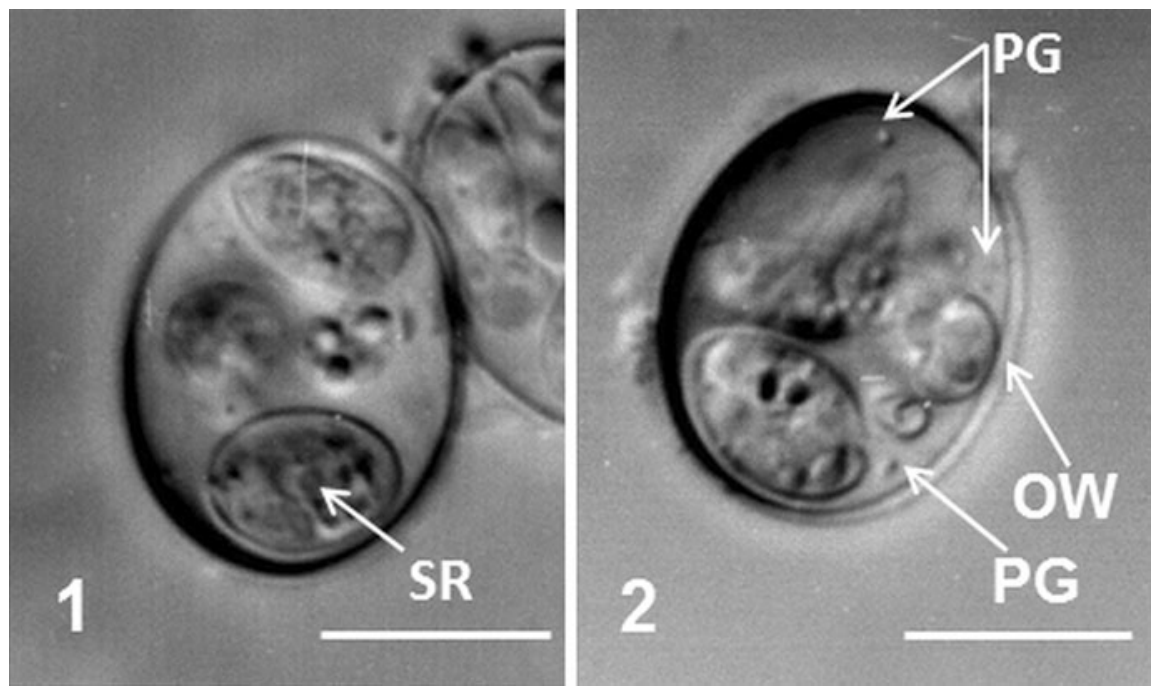

Figs. 1-2 Oöcysts of Eimeria perkinsae n. sp. 1, Oöcyst showing sporocyst residuum (SR); 2, Oöcyst showing oöcyst wall (OW) and fragmented polar granule (PG). Scale-bars: $10 \mu \mathrm{m}$

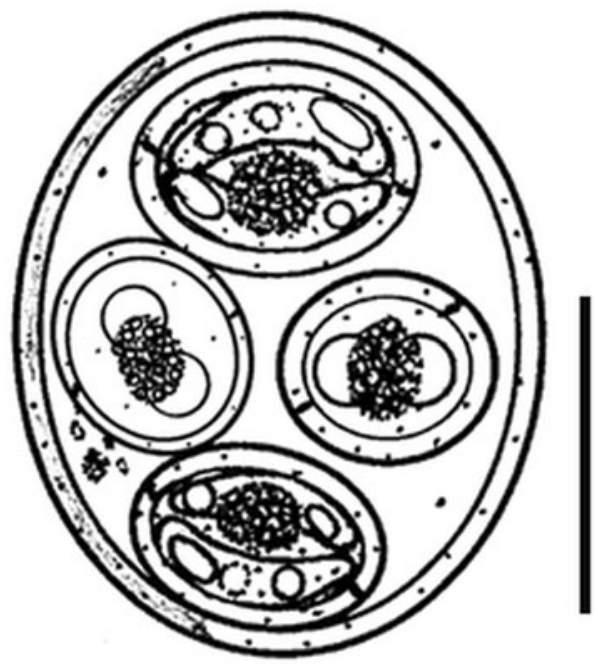

Fig. 3 Composite line drawing of oöcyst of Eimeria perkinsae n. sp. Scale-bar: $10 \mu \mathrm{m}$

Lampropholis guichenoti (Duméril \& Bibron) from Australia (Cannon, 1967) and Eimeria leiolopismatis Cannon, 1967 from orange-tailed shadeskink, Saproscincus challengeri (Boulenger) from Australia (Cannon, 1967). However, sporocysts of E. lampropholidis are smaller than $E$. perkinsae $(7.7 \times 6.5$ vs $8.9 \times 6.4)$ and do not possess a polar granule; sporocysts of $E$. leiolopismatis are described as being ellipsoidal whereas those of $E$. perkinsae are ovoidal. In addition, the host of E. perkinsae n. sp., S. solomonis, belongs to the "Sphenomorphus group" and Saproscincus is in the "Eugongylus group", which means they are phylogenetically distant and, therefore, would not be expected to share coccidia (see figure 1 of Skinner et al., 2011).

\section{Discussion}

The genus Sphenomorphus is a large complex group of skinks that is poorly known systematically, especially due to their conservative morphology (Linkem et al., 2011). Recent molecular systematic work has shown that the true species diversity in this genus is probably best represented by breaking the group into multiple monophyletic genera (Linkem et al., 2011).

The natural history of Sphenomorphus species is quite varied, with species living on the ground, in trees, and fossorially. Of the species studied here, only S. solomonis is fossorial, typically collected under surface material such as logs and rocks in primary and secondary rain forest. The new species represents the first coccidian from a fossorial Pacific skink, and continues the trend of generic specificity in coccidians in skinks of the Pacific (Modrý \& Jirků, 2006; McAllister et al., 2013a, b, c, d). A broader sampling of sites and species within the current genus Sphenomorphus is likely to discover many additional endemic coccidian species. 
Acknowledgements We thank the late Steve J. Upton (Kansas State University, Manhattan, KS, USA) for technical assistance, and Scott L. Gardner (Manter Parasite Collection, Lincoln, NE, USA) for parasitological training of RNF. Further appreciation is extended to Patricia A. Pilitt (USNPC) for expert curatorial assistance. The PNG Department of Environment and Conservation supplied export permits to CCA and RNF for the lizard and parasite collections. This work was funded in part by DEB 1146033 to CCA. The use of trade, product, or firm names in this publication does not imply endorsement by the U.S. Government.

\section{References}

Austin, C. C., \& Perkins, S. L. (2006). Parasites in a biodiversity hotspot: A survey of hematozoa and a molecular phylogenetic analysis of Plasmodium in New Guinea skinks. Journal of Parasitology, 92, 770-777.

Cannon, L. R. G. (1967). New coccidia from Australian lizards. II. Eimeria. Parasitology, 57, 237-250.

Bursey, C. R., Goldberg, S. R., \& Kraus, F. (2005). Endoparasites in Sphenomorphus jobiensis (Sauria: Scincidae) from Papua New Guinea with description of three new species. Journal of Parasitology, 91, 1385-1394.

Goldberg, S. R., Bursey, C. R., \& Kraus, F. (2009). Endoparasites in 12 species of Sphenomorphus (Squamata: Scincidae) from Papua New Guinea. Comparative Parasitology, $39,58-83$.

Goldberg, S. R., Bursey, C. R., \& Kraus, F. (2010). Metazoan endoparasites of fourteen species of skinks (Squamata: Scincidae) from Papua New Guinea. Journal of Natural History, 44, 447-467.

Kreis, H. A. (1940). Beitrage zur Kenntnis parasitischer Nematoden. IX. Parasitische Nematoden aus dem Naturhistorischen Museum Basel. Centralblatt für Bakteriologie, Parasitenkunde und Infektionskrankheiten, 145, 163-208.

Linkem, C. W., Diesmos, A. C., \& Brown, R. M. (2011). Molecular systematics of the Philippine forest skinks (Squamata: Scincidae: Sphenomorphus): testing morphological hypotheses of interspecific relationships. Zoological Journal of the Linnean Society, 163, 1,217-1,243.
McAllister, C. T., Duszynski, D. W., \& Fisher, R. N. (2013a). Two new species of Isospora (Apicomplexa: Eimeriidae) from skinks, Emoia spp. (Sauria: Scincidae) from Fiji and Papua New Guinea. Journal of Parasitology, 99, 677-679.

McAllister, C. T., Duszynski, D. W., Fisher, R. N., \& Austin, C. C. (2013b). A new species of Eimeria Schneider (Apicomplexa: Eimeriidae) from Carlia spp. (Sauria: Scincidae) from Papua New Guinea. Systematic Parasitology, 86, 53-57.

McAllister, C. T., Duszynski, D. W., Austin, C. C., \& Fisher, R. N. (2013c). Three new species of coccidia (Apicomplexa: Eimeriidae) from skinks, Lipinia spp. (Sauria: Scincidae), from Oceania. Journal of Parasitology, 99 (in press).

McAllister, C. T., Seville, R. S., Duszynski, D. W., Bush, S. E., Fisher, R. N., \& Austin, C. C. (2013d). Two new species of Eimeria (Apicomplexa: Eimeriidae) from emerald tree skinks, Lamprolepis smaragdina (Sauria: Scincidae) from Papua New Guinea and the Philippines. Systematic Parasitology, 86, 165-171.

Modrý, D., \& Jirků, M. (2006). Three new species of coccidia (Apicomplexa: Eimeriorina) from the marble-throated skink, Marmorosphax tricolor Bavay, 1869 (Reptilia: Scincidae), endemic to New Caledonia with a taxonomic revision of Eimeria spp. from scincid hosts. Parasitology Research, 99, 416-428.

Perkins, S. L., \& Austin, C. C. (2009). Four new species of Plasmodium from New Guinea skinks: integrating morphology and molecules. Journal of Parasitology, 95, 424-433.

Skinner, A., Hugall, A. F., \& Hutchinson, M. N. (2011). Lygosomine phylogeny and the origins of Australian scincid lizards. Journal of Biogeography, 38, 1,044-1,058.

Uetz, P. (2013). The TIGR Reptile Database. World Wide Web electronic publication. http://www.reptile-database.org/. Accessed 30 April 2013.

Wilber, P. G., Duszynski, D. W., Upton, S. J., Seville, R. S., \& Corliss, J. O. (1998). A revision of the taxonomy and nomenclature of the Eimeria spp. (Apicomplexa: Eimeriidae) from rodents in the Tribe Marmotini (Sciuridae). Systematic Parasitology, 39, 113-135.

Zug, G. R. (2013). Reptiles and amphibians of the Pacific Islands: a comprehensive guide. Berkeley: University of California Press, 320 pp. 